\title{
Impact of Cynicism Behaviour on Employee Engagement
}

\author{
B.DIVYA ${ }^{1}$, R.SERANMADEVI ${ }^{2}$ \\ VEL TECH RANGARAJANDR.SAGUNTHALA R\&D INSTITUTE OF SCIENCE AND TECHNOLOGY, INDIA. \\ ${ }^{1}$ E-mail: divyabalakrishnan1989@gmail.com \\ 2E-mail: Seranamadevi@gmail.com
}

\begin{abstract}
An employee is the pillar of strength in an organization, his contribution towards work is vital. Several problems are faced by an employee while working in the organization; it can be in the form of his work-life balance, interpersonal relationship with his superiors or colleagues, health issues, job satisfaction, and job commitment. The word 'Cynicism' denotes the belief that people always act selfishly. Employee cynicism refers to an attitude that arises due to frustration, hopelessness etc. Nowadays,employers are willing to recruit an employee who is engaged in the organization for a long period. Engaging an employee with the organization is a difficult task. employee engagement insists to make an employee aligning with the company vision, mission, and goals. The researcher wants to study the impact of Cynicism behavior on Employee Engagement at the workplace.
\end{abstract}

Keywords: Cynicism; Employee; Engagement; Interpersonal relationship; Retention.

JEL Classification: C1, L2 


\title{
Impacto del Comportamiento de Cinismo en el Compromiso de los Empleados
}

\author{
B.DIVYA ${ }^{1}$, R.SERANMADEVI ${ }^{2}$ \\ VEL TECH RANGARAJANDR.SAGUNTHALA R\&D INSTITUTE OF SCIENCE AND TECHNOLOGY, INDIA. \\ ${ }^{1}$ E-mail: divyabalakrishnan1989@gmail.com \\ 2E-mail: Seranamadevi@gmail.com
}

\begin{abstract}
RESUMEN
Un empleado es el pilar de la fuerza de una organización, su contribución al trabajo es vital. Un empleado se enfrenta a varios problemas mientras trabaja en la organización; puede ser en forma de equilibrio entre la vida laboral y la personal, la relación interpersonal con sus superiores o compañeros, los problemas de salud, la satisfacción laboral y el compromiso laboral. La palabra "cinismo" denota la creencia de que las personas siempre actúan de forma egoísta. El cinismo de los empleados se refiere a una actitud que surge debido a la frustración, la desesperanza, etc. Hoy en día, los empresarios están dispuestos a contratar a un empleado que se comprometa con la organización durante un largo periodo. El compromiso de un empleado con la organización es una tarea difícil. El compromiso de los empleados insiste en hacer que un empleado se alinee con la visión, la misión y los objetivos de la empresa. El investigador quiere estudiar el impacto del comportamiento de cinismo en el compromiso de los empleados en el lugar de trabajo.
\end{abstract}

Palabras clave: Cinismo; Empleado; Compromiso; Relación interpersonal; Retención.

Clasificación JEL: C1, L2

Recibido: 02 de Junio de 2021

Aceptado: 28 de Septiembre de 2021 


\section{Introduction}

The word cynicism is often traced back to fourth century Greece. a gaggle of philosophers who called themselves as followers of Antisthenes very openly questioned the existence of state and non-secular institutions. Many believed that these followers Antisthenes flouted public opinion or public convictions simply for the sake of doing so, and deemed these followers as disciples of the dog, or Cynics. However, as time progressed (third century), Cynicism was revived as a faculty of thought and propagated the thought of mockery of convention and tradition and prevailing beliefs and modes of behavior.

It was found that most of the employees leave their job because they losetrust in their employer and when their economic conditions improve they leave their current job for another.

Cynicism denotes people only think about themselves and does not care about others, usuallythey are not sincere and honest,their attitude and behavior will harm others.

\section{Review Of Literature}

Arslan and Roudaki (2019) studied the impact of organizational cynicism on employee performance.The importance of employee engagement on organizational cynicism and employee performance have been studied in their research. The scale used for measuring employee engagement is Schaufeli et al. (2006). The data is collected through a questionnaire and the participants of the study include employees working in health organizations in Pakistan. It was found in the study organizational cynicism has a negative impact on employee performance. Due to the poorer employee performance, patient care is being compromised in health care organizations. To conclude Employee engagement features a moderating effect on organizational cynicism and employee performance.Employees feel that the organizations are not paying attention to their career development and not fulfilling their promises, this must be rectified by the managers and organizations in order to keep employees for the long run.

Durrah et al. (2019) studied the relationship between organizational cynicism and organizational pride. The study helps in measuring organizational cynicism and therefore the degree of organizational pride among the workers working in industrial organization. The sample of study includes nine industrial organizations located in Oman. Through a structured questionnaire, the data is collected from the employees. The dimensions of organizational cynicism are affective cynicism and behavioral cynicism, it was found within the study the size of organizational cynicism has a big and negative impact on emotional pride.

Erarslan et al. (2018) they explored the extent to which organizational cynicism and job satisfaction affects organizational commitment. In order to cope up with the strategies and goals of organization employees, work harder to achieve it. Employee performance plays an important role in this aspect. When an employee shows negativism towards the organization, or with his colleagues there arises cynicism. Increased work pressure, stiff competition, stress level of employees affects the attitude and behavior of employees. Through questionnaire the data is collected from employees working in the banking sector. The results show there is a positive effect on organizational commitment and job satisfaction. If there is an environment of trust in the organization the cynicism would disappear. Promotion and appreciation by the managers will decrease the cynic culture among employees.

Abugre (2017) explore to propose a process model that shows how the employees' positive relationship at the workplace impacts negatively on their cynical behaviorsin organization driving with the intention to stay and not to leave the organization. The study is a conceptual paper. When the workers feel the connection of organization and co-Workerstowards them are negative then become cynical and show a negative attitude towards the organization. If there's a positive coworker relation within the organization, then there's job satisfaction and commitment of 
employees. Whereas if there prevails negative co-worker relations it'll cause cynicism, diminished loyalty, intention to go away the organization.

Anitha. J (2014) studied in their paper to find out the factors which affect employee engagement. The study aims to find the impact of employee engagement on employee performance. The factors that impact more employee engagement are the working environment and team and co-worker relationship. From the study, it is inferred that employee engagement had a significant impact on employee performance. Finally, a validated model has been developed on the impact of employee engagement on employee performance.

\section{Research Gap}

Many studies have been conducted to study the impact of organizational cynicism on employee engagement among the employees working in Health Care Professionals, and few researches also studied the relationship in Workplace, Cynicism and other factors that affect employees to leave the organization. The impact of cynicism behavior on employee engagement is not widely examined in the literature. The researcher targets the employees working in manufacturing companies and attempted to study the reasons employee Cynicism occurs in the organization and turn how it affects employee behavior and their engagement level in the organization. In the present study,the impact of cynicism behavior is analyzed through organizational commitment and employee relationships with co-workers have been taken for measuring the cynicism factor.

\section{Objectives}

The following are the research objectives framed to study the relationship behavior of the employees at workplace and their level of commitment based on the impact of cynicism

- To investigate the relationship of employees with their co-workers.

- To evaluate the organizational commitment of employees in their workplace.

- To assess the effect of employee cynicism on employee engagement.

\section{Research Methodology}

\subsection{Research design and paradigm}

This research followed a descriptive research design which studies the impact of cynicism behavior on employee engagement and commitment in the workplace.

\subsection{Target Population and Unit of Analysis}

The target population of the study includes employees who are working in the manufacturing companies at the floor level. Since the lower-level employees are highly responsible for carrying out and executing the organization's activities.

\subsection{Sample Size and Sampling Technique}

Disproportionate to the total population of employees, a sample of 25 employees have been included from four different companies to construct a sample size of 100 based on stratified random sampling technique, each company is assumed as one strata. In the study survey is taken by personal opinion ie.through face-to-face interview was used to collect the primary data in the working sites during the working hours.

\subsection{Instrument development}

In this research study, the major instrument for collecting the data administered a structured questionnaire. The questionnaire consists of 12 questions segregated into 5 parts:

- Part 1 consists of theDemographics profile of respondents 
- $\quad$ Part 2 focused on the factors specified for working in the current job.

- Part 3 represents the organizational commitment level of employees.

- Part 4 consists of employee engagement factors.

- Part 5 includes the employee cynicism and relationship with co-workers.

The survey questions on organizational cynicism and job satisfaction used in the study were taken from Erarslan, S., Kaya, C., Altindag, E., (2018), and questions of the Organizational Cynicism survey questions were taken from Faith Turkmen, Emre Aykac (2017). From the Organizational Climate Questionnaire by Adrian Furnham and Leonard D.Goodstein(1997), the factors of employee cynicism have been taken for the study.

\subsection{Methods of Data Analysis}

The analysis is carried out by using IBM SPSS software Version 16.

\section{Research Findings}

\subsection{Demographics Analysis}

Table 1: Demographic Profile of Respondents

\begin{tabular}{|c|c|c|c|}
\hline S.No & Particulars & Frequency & Cumulative Frequency \\
\hline 1 & \multicolumn{3}{|c|}{ Age } \\
\hline & 20-30 Years & 66 & 66 \\
\hline & $31-40$ Years & 24 & 90 \\
\hline & 41-50 Years & 08 & 98 \\
\hline & 51-60 Years & 02 & 100 \\
\hline 2 & \multicolumn{3}{|c|}{ Gender } \\
\hline & Male & 49 & 49 \\
\hline & Female & 51 & 100 \\
\hline 3 & \multicolumn{3}{|c|}{ Marital Status } \\
\hline & Married & 50 & 50 \\
\hline & Single & 50 & 100 \\
\hline 4 & \multicolumn{3}{|c|}{ Educational Qualification } \\
\hline & Graduate & 27 & 27 \\
\hline & Post Graduate & 48 & 75 \\
\hline & Professional & 24 & 99 \\
\hline & Others & 01 & 100 \\
\hline 5 & \multicolumn{3}{|c|}{ Years of Experience } \\
\hline & $0-1$ Years & 39 & 39 \\
\hline & 1-2 Years & 24 & 63 \\
\hline & 2-3 Years & 15 & 78 \\
\hline & 3-4 Years & 08 & 86 \\
\hline & Above 5 Years & 14 & 100 \\
\hline 6 & \multicolumn{3}{|c|}{ Designation } \\
\hline & Lower Level & 18 & 18 \\
\hline & Middle Level & 70 & 88 \\
\hline & Upper Level & 12 & 100 \\
\hline 7 & \multicolumn{3}{|c|}{ Salary } \\
\hline & Below Rs.20000 & 37 & 37 \\
\hline & Rs.20001-30000 & 29 & 66 \\
\hline & Rs.30001-40000 & 22 & 88 \\
\hline & Above 50000 & 12 & 100 \\
\hline
\end{tabular}

(Source: Questionnaire). 
Table 1 shows the demographic characteristic of the respondents. Majority of the respondents(66\%) arein the age group of $20-30$ years. Most of the respondents $(48 \%)$ are postgraduates working in the companies. Equal weightage was given between male and female and married and single category respondents when collecting the primary data. The respondents group consists most recently joined employees having 0-1 year of experience in the present organization. There are more number of middle-level employees are included in the study under the salary status of below Rs. 20,000 .

\subsection{Mean Average}

Table 2: Organizational Commitment Level of Employees

\begin{tabular}{|c|l|c|c|c|c|c|c|c|}
\hline S.No & \multicolumn{1}{|c|}{ Opinion } & SA & A & N & DA & SDA & Avg & Rank \\
\hline 1 & $\begin{array}{l}\text { I feel "emotionally linked" to the } \\
\text { business I work for. }\end{array}$ & 30 & 38 & 19 & 11 & 02 & 3.83 & 2 \\
\hline 2 & $\begin{array}{l}\text { Because of the commitments, I work in } \\
\text { this company rather than working } \\
\text { happily. }\end{array}$ & 10 & 32 & 36 & 15 & 07 & 3.23 & 6 \\
\hline 3 & $\begin{array}{l}\text { I think it's not right for me to leave the } \\
\text { company for which I work, even though } \\
\text { it's beneficial to me. }\end{array}$ & 18 & 26 & 39 & 12 & 05 & 3.40 & 4 \\
\hline 4 & $\begin{array}{l}\text { My chances of finding another job are } \\
\text { restricted if I quit the company for } \\
\text { which I work. }\end{array}$ & 20 & 34 & 22 & 13 & 11 & 3.39 & 5 \\
\hline 5 & $\begin{array}{l}\text { It makes me very excited to spend time } \\
\text { in the organization. }\end{array}$ & 38 & 39 & 18 & 3 & 2 & 4.08 & 1 \\
\hline 6 & $\begin{array}{l}\text { I putted myself with hardwork in the } \\
\text { organization so I think should leave. }\end{array}$ & 25 & 40 & 23 & 5 & 7 & 3.71 & 3 \\
\hline
\end{tabular}

(Source: Questionnaire)

The above table presents the organizational commitment level of employees and it was analyzed with the help of mean averageand it employees feel happy to work with the organization. It shows that employees are also emotionally connected to the organization they work for. They also agreed that they worked very hard in the organization so that they should leave the organization. Employees feel if they leave the organization they are working with the chances of finding another job are limited outside. The organizational commitment level of employees reveals because of the obligations in the organization the employees work, rather than working willingly.

Table 3: Factors of Employee Engagement

\begin{tabular}{|c|l|c|c|c|c|c|c|c|}
\hline S.No & \multicolumn{1}{|c|}{ Opinion } & SA 5 & A 4 & N 3 & DA 2 & SDA 1 & Avg & Rank \\
\hline 1 & $\begin{array}{l}\text { I think my company says that one thing } \\
\text { does another thing. }\end{array}$ & 15 & 24 & 33 & 21 & 7 & 3.19 & 2 \\
\hline 2 & $\begin{array}{l}\text { I'm talking to my colleagues about how } \\
\text { the organization's work is being } \\
\text { performed. }\end{array}$ & 26 & 53 & 13 & 8 & - & 3.97 & 1 \\
\hline 3 & $\begin{array}{l}\text { I feel aggravation when I think my } \\
\text { organization. }\end{array}$ & 10 & 29 & 29 & 21 & 11 & 3.06 & 3 \\
\hline 4 & $\begin{array}{l}\text { I criticize my organization's policies and } \\
\text { practices to outsiders. }\end{array}$ & 11 & 21 & 26 & 19 & 23 & 2.78 & 5 \\
\hline 5 & $\begin{array}{l}\text { I feel jealous if my co-worker is being } \\
\text { promoted to the next level. }\end{array}$ & 18 & 09 & 33 & 20 & 20 & 2.85 & 4 \\
\hline 6 & I am not honest in the organization. & 07 & 17 & 09 & 31 & 36 & 2.28 & 6 \\
\hline 7 & I have trust with my supervisor. & 30 & 44 & 19 & 7 & - & 3.97 & 1 \\
\hline
\end{tabular}


Table 3 presents the Engagement level of employees in their workplace, it is inferred from the table the Mean value is high for the factors employees have trust with their supervisors and they talk with the colleagues how the work is being carried out in the organization. The employees believe that the organization says one thing and does another thing; they also feel irritated when they think about their organization.

When a co-worker is being promoted in the organization the employee feels jealous about it so here occurs the employee cynicism factor. They also find faults with the organization policies and practices and criticize them to the outsiders.

Table 4: Employee Cynicism \& Relationship with Co-Workers

\begin{tabular}{|c|l|c|c|c|c|c|c|c|}
\hline S.No & \multicolumn{1}{|c|}{ Opinion } & SA 5 & A 4 & N 3 & DA 2 & SDA 1 & Avg & Rank \\
\hline 1 & My superior not treats me with respect. & 02 & 12 & 16 & 54 & 16 & 2.30 & 7 \\
\hline 2 & $\begin{array}{l}\text { My superior does not handle work- } \\
\text { related issues satisfactorily. }\end{array}$ & 09 & 16 & 40 & 22 & 13 & 2.86 & 1 \\
\hline 3 & $\begin{array}{l}\text { My superior is not an effective } \\
\text { manager. }\end{array}$ & 11 & 05 & 25 & 43 & 16 & 2.52 & 3 \\
\hline 4 & $\begin{array}{l}\text { My superior does not like to consult } \\
\text { him/her before I take action. }\end{array}$ & 05 & 17 & 24 & 41 & 13 & 2.60 & 2 \\
\hline 5 & $\begin{array}{l}\text { I do not feel valued by my colleagues in } \\
\text { the department. }\end{array}$ & 07 & 06 & 26 & 50 & 11 & 2.48 & 5 \\
\hline 6 & $\begin{array}{l}\text { I do not value my colleagues in the } \\
\text { department. }\end{array}$ & 01 & 09 & 29 & 44 & 17 & 2.33 & 6 \\
\hline 7 & \begin{tabular}{l} 
I have trust with my supervisor. \\
\hline
\end{tabular}
\end{tabular}

Table 4 indicates, majority of the employees feelthat their superior does not handleworkrelatedissues satisfactorily. The superior does not like to consult him before the employees take decisions and they will not help the employees in sorting out the problems. Most of the employees feel that their superiors are not a productive manager in the organization. When it comes to relationship with co-worker the employees undergo they are not valued by their colleagues in the department.

\section{Implication Of Study}

From the research study, it clearly indicates the employees were emotionally connected with the organization they are working and they feel happy when they are working in the organization in accomplishing their goals. When it comes to engagement level of employees there exists trust with their superiors and only a few employees'feels that they feel jealous when their co-worker is promoted to the next level. Employees should be fairly treated is the critical element in employee engagement and satisfaction in the workplace, the superior does not treat them fairly the morale of the employees will be decreased and their engagement level will be below.

From the findings, it is inferredthe superior does not handle work-related issues satisfactorily in the organization. Employee cynicism occurs when the employee feels a cause of irritation and frustration when they think about their organization. It is the duty of the superior to be the backbone in developing an employee. They should act as a communicator with the employees in accomplishing the organizational needs, overseeing the employees' performance, guiding to them wherever they needed and to support them.

\section{Conclusion}

If an employee is frustrated in their work they cannot engage themselves in their work properly, low engagement leads to low productivity with poor performance. Hence occurs the concept of cynicism. Past research focused on the impact of organizational cynicism on employee performance and employee engagement, job satisfaction. The relationship with co-workers is one of the major 
factors which affect the commitment level of employees in a workplace. If the employee does not align with the goals of the organization there exists cynicism, the attitude and behavior of employees will be changed because of the negative attitude of employees towards their organization. It is the obligation of superior in knowing how to deal with the frustrated employee. Motivating the employees in their work serve as a tool in eradicating their irritation.Causes of cynicism leads to anger, disrespectful body language or aggression at work. Responsibility of the superior lies in listening to the employees grievances rather than reacting to them immediately.

\section{Referencies}

1.Abraham, R. (2000). Organizational cynicism bases and consequences, Genetic, Social and General Psychology Monographs, 126 (3), 269-292.

2.Abugre, J. B. (2017). Relations at workplace, cynicism and intention to leave: A proposed conceptual framework for organisations. International Journal of Organizational Analysis, 25(2), 198-216.

3.Adrain Furnham and Leonard D.Goodstein (1997). The organizational Climate Questionnaire(OCQ),The 1997 Annual,2,163-179.

4.Anitha, J., (2014). Determinants of employee engagement and their impact on employee performance. International Journal of Productivity and Performance Management, 63(3), 308323.

5.Arslan, M., \& Roudaki, J. (2018). Examining the role of employee engagement in the relationship between organisational cynicism and employee performance.International Journal of Sociology and Social Policy, 39(1-2), 118-137.

6. Aslan, H., \& Yilmaz, E. (2013). The Study of Teachers' General Cynicism Inclinations in Terms of Life Satisfaction and Other Variables. Creative Education, 04(09), 588-591.

7.Brandes, P., Dharwadkar, R. and Dean Jr., J.W. (1999). Does Organizational Cynicism Matter? Employee and Supervisior Perspectives on Work Outcomes. The 36th Annual Meeting of the Eastern Academy of Management, Philadelphia, 1-33.

8.Durrah, O., Chaudhary, M., \& Gharib, M. (2019). Organizational cynicism and its impact on organizational pride in industrial organizations. International Journal of Environmental Research and Public Health, 16(7), 4-6.

9.Erarslan, S., Kaya, C., Altindag, E., (2018). Effect of organizational cynicism and job satisfaction on organizational commitment: An empirical study on banking sector. The journal of faculty of economics and administrative sciences.23, 905-922.

10.Faith Turkmen, \&Emre Aykac (2017). The Association Between Organizational Cynicism and Organizational Citizenship Behaviour: A case study,European Research Studies Journal, 20(4), 742753.

11.Schaufeli, W. B., Bakker, A. B., \& Salanova, M. (2006). The Measurement of Work Engagement With a Short Questionnaire:A Cross-National Study, Educational and Psychological Measurement,66(4), 701-716. 